\title{
Go organic: Sustainable marketing goals - Chandigarh organic market
}

Dr. Chidanand Patil ${ }^{1}$, Assistant Professor, Department of Applied Agriculture, Central University of Punjab, Bathinda, Punjab, India. Email: chidusam@gmail.com.

Ms. Aarti Rishi ${ }^{2}$, Management Trainee, Punjab Agri Export Corporation Limited, Chandigarh, India.Email: aartirishi995@gmail.com.

Dr. Shivam Sakshi ${ }^{3}$, Postdoctoral Associate, Economics and Social Science, IIM Bangalore, Karnataka, India. Email: shivamsa@iimb.ac.in.

Dr. Chaitra G. ${ }^{4}$, Former Assistant Professor, Department of Management and Commerce, Malwa College, Bathinda, Punjabi University, Patiala, Punjab, India. Email: chaitragb519@gmail.com.

\section{Introduction:}

The demand for organic food products is multiplying gradually across Punjab. The green revolution has definitely solved the world's hunger problem by boosting the agricultural production but it did not take long for people of Punjab to realize the adverse effects they have to face due to the extensive utilization of such chemicals which are strictly banned in many nations for their adverse effects. The life-annihilating chemicals that are being sprinkled into crops are classified into class one by the World Health Organization, which are the most toxic and banned in most of the countries (The Guardian on July 1,2019). The only way to address this catastrophe is to change the food consumption habits. Shifting to organic food could not only reduce the risk of cancer but can also improve the overall health conditions.

In August 2015 with the realization of Mrs. Raman Mann, a farmer and an activist has realized that the marketing is the major issue in organic food space and the production is not a pinnacle to work on. She then decided to establish a sustainable market, "a market which only sounded hypothetical in organic food space back in 2015" she recollected. She envisioned a market which is consumer oriented, environment friendly and farmer led. In organic food business the marketer is most of the times highly vulnerable to many external factors. The major drawback is the premium price a customer has to pay. As no chemicals are used in the organic food production the yield is comparatively lesser than that of chemical fed production practices which makes the farmer/marketer/seller to charge a premium price for their produce.

The established market depicts its abilities to handle the three very important pillars of sustainable marketing which are

1. Social 
2. Environmental

3. Financial

The organic food supply through the market is ensuring consumer's health, non usage of chemicals for agricultural production ensures the environmental protection and the most important goal of the market, financial liberty of farmer cum sellers due to no middle man.

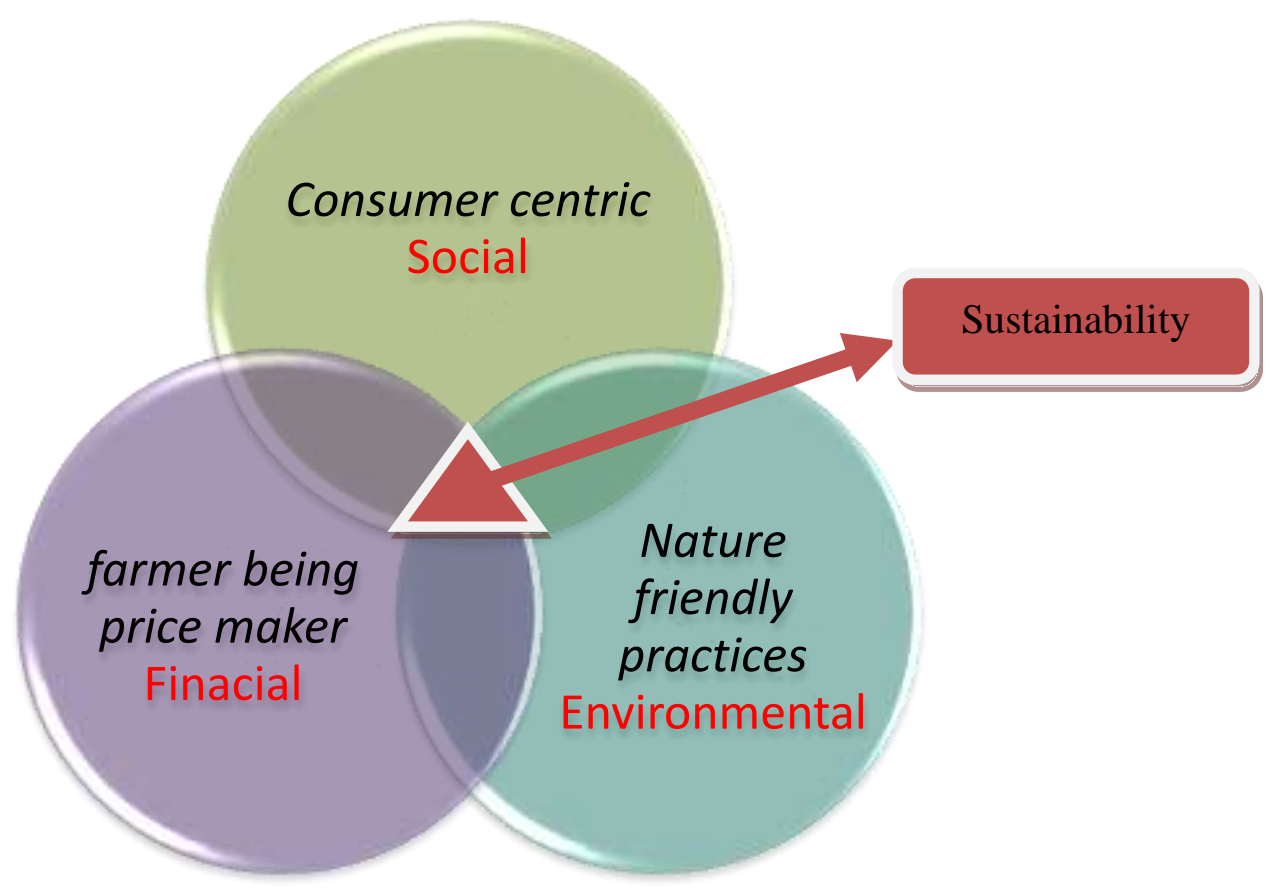

Source: Author's own work

\section{Organic - the new old way! / back to basics}

The initiator of Chandigarh organic market Mrs. Raman Mann is a farmer herself with thoughts of prosperity. She was able to sense the importance of a market with sustainable marketing practices. The terrifying facts of prone health hazards have exponentially raised the awareness of organic foods among the people of Punjab. The escalation of production, marketing, procurement and sales of organic foods had eventually increased across Punjab. She wanted to cease this opportunity to establish a market which would eventually be an example of sustainable market. This market focuses on 3 goals

1. Social cause: the market sells products which are grown completely with organic practices. Inculcating a healthy lifestyle among the consumers is of major concern of the organizers of the market. 
2. Environmental cause: the market sells only those agricultural produce which are grown organically. No chemicals in farming means no harm to the nature. Fertilizers, pesticides, etc. which are commonly used highly degrades the soil.

3. Financial cause: the sellers in the market are the farmers themselves. There are absolutely no middlemen. This practice results in farmer taking the whole of the profit.

Organic farming is not novel in India, it has been around since a few thousand years. Only due to chemical utilization giving humongous yield, the age-old organic practices are left behind. "The organic food production has never been a difficult task but the after-cultivation part is a nightmare" said a farmer cum seller of the market. The organic food market was not expected to blossom with no efforts. Mrs. Raman Mann knew that it would take a lot of efforts and still there was no guarantee, she did it anyway. She gathered a few farmers who were willing to practice organic farming and got them all on board to establish the organic market with no middlemen, with no price makers from outside, with least wastage, with superior customer relationship, with excellent sustainable practices.

\section{Lessons learned:}

1. Societal marketing: Influence of a business on the society always plays an influential role in the enhancement of the business itself. Wellbeing of the target customer/consumers when taken care of, such business certainly has a great edge in terms of competitive advantage.

The market aims at achieving sustainable competitive advantage through the implementation of societal marketing concept. The market has been set up on the principle of benefitting the society by inculcating organic practices into cultivating the crops. Food safety, human health and environmental concerns influence the organic food consumer preferences. This organic food market has considered the human welfare as its top priority over profits. It makes sure to satisfy the consumers' wants and needs. The health of the consumer is the prime factor under consideration while developing a marketing strategy that benefits the farmers and takes care of the environment, society as well as the consumer. Health consciousness is the fundamental factor considered by both the farmers and the consumers to add their bit into the sustainable environmental practices. Farmers believe and prefer in satisfying long-run well-being of society over the short-term needs of the individual consumers by producing and marketing healthy organic farm produce. Farmers also educate consumers about the ethical, environmental and societal benefits of production and consumption of organic food which is leading the consumers to exhibit higher levels of health orientation and socially responsible consumption behavior.

2. Build loyal customer base: Quality of the produce/product/service retains the consumers in spite of minimal efforts and advertisements. Better the business's service more is its reach. Trust is another most important ingredient to develop loyal customer base. 
Every week the same consumers visit the market as well as they advocate the market to their acquaintances. These consumers themselves have been the reasons for driving the market to success by believing in the farmers along with the determination of the farmers. These consumers have themselves become a brand ambassador of the market and speak for it and the benefits of consuming organic produce. Because of their utter hard work, the farmers have gained the trust of these consumers which resulted in a loyal customer base which in turn helped the farmers to make accurate forecast of production as well as the sales of the organic farm produce in the market. The extensive loyal nature of the consumers has also allowed the farmers to introduce product extensions in the market like processed food products, chips, carrot cakes, bakery products, etc. Despite of presence of number of organic food outlets across the city of Chandigarh, the trust which is created among the customers drives them to this market.

3. Efficient demand estimation: The demand estimates are the most important factor for a company's production channel. Understanding of purchase behavior of the consumers will also help in dump minimization which is important because nearly 16 percent of fruits and vegetables are wasted every year (Financial Express Newspaper, 2019) in India.

The farmers know the purchase behavior of the consumers. They are now able to estimate the purchase quantity of the consumers every week, which has helped in planning their production activities according to the demand in the market. Because the consumers are regular in nature and their purchase quantity is also known. As the customers' demand is well known by the producer, the farmers produce and bring appropriate quantity of produce to the market which helps in minimal wastage. The fruits and vegetables are perishable in nature and also the farmers do not have any cold storage facilities but still they are able to market all their food products without dumping in the market. In many cases, companies approach the organic markets/producers for contract farming to get an assured supply of farm produce for a preagreed price and quality parameters. But in this market without any sort of contractual arrangements, the planned production and marketing activity is happening based on the trust and loyalty of the consumers over the farmer's produce.

4. Let the customer know the business: A well learnt customer appreciates the product or service better. Educating the customer with the basics of the business enriches their trust and interest in it.

Consumer trust is a key pre-requisite for establishing a market for credence goods such as organic food products, especially when they are premium priced. Many consumers believe that the products sold organic are not really organic. Usually, consumers rely on partial information to assess the quality of organic food and are not in a position to determine its authenticity with certainty. This market allows the consumers to visit the farmers' fields and know and understand their practices of growing the organic food. The concept of 'Know Your 
Farmer and Know Your Food' is highly supported and practiced through the market and its consumers. The consumers can also learn how the farmers are cultivating the food they consume. The consumers however, interact with the farmers while making their purchases to gain knowledge and clear their doubts if any regarding the practices used by them. One more reason for establishment of trust between farmers and consumers in this market is that, the consumer knows the farmer and farmer himself is producing and selling the product, and there are no middlemen in this direct marketing channel. 'Seeing is believing' is the principle which is being practiced in this market through field visits of the consumers. Through this the consumers have developed a trust about the produce which they are purchasing in this market. This sort of field visits has not only encouraged to develop a trust but also to get a deeper understanding of the agriculture, organic farming practices, farmers problems in production and marketing.

5. Distribution channel efficiency: No wastage is better than zero wastage. Marketing intermediaries always comes with a price to be borne both by either producer or by consumer or in some cases both.

Most of the farm products reach consumers through several middlemen and distribution channels. But in this market, as farmers are directly selling their produce to the consumers, they get 100 percent of share in the consumers' rupee. The farmers are price makers in this market. Otherwise in majority of the cases the farmers are price takers due to their low bargaining power. In this market, the price of the commodities are fixed by the farmers and it is usually the prevailing market price of the supermarkets in the city for the organic produce and the price is usually 3 to 4 times higher when compared to the in-organic produce. The consumers don't bargain for the price because they know that the yield of the organic produce will be low, hence, the price is high and it is observed that the consumers aren't bother about paying a higher price for the organic produce. The farmers do not make an attempt to attract the consumers by offering special discounts or marketing promotions since they believed that their consumers are knowledgeable and would be willing to pay a premium price for such produce which is worth it. The price is not the important thing in determining the perceived value of the consumers towards purchase intention of the organic food produce in this market.

\section{Synopsis:}

"The problem is not production but marketing" - This is the common scenario of majority of organic food producers in India. This case examines the strategies adopted by a group of farmers in marketing their organic food products by adopting sustainable marketing practices in Chandigarh city of India. The organic food produce usually comes with a high price tag due to its low yield and establishing trust with the consumers is one more challenge in its marketing, as the consumer thinks twice while making a purchase decision as he is paying a 
higher price as compared to the inorganic food. In this organic market the farmers are the price makers not the price takers. How the market has established a consumer centric, environment friendly sustainable marketing practices by taking into account the risks associated with the financials of farming and trust of the consumer?

\section{Research Methodology}

This case was developed mainly from the primary sources. The primary sources included the interviews with the Mrs. Raman Mann, the founder of this organic food market in Chandigarh city in India, farmers who are selling their organic food produce in this market and the consumers who are visiting this market.

\section{Target Audience}

This case will help business knowledge seekers in understanding the sustainable marketing practices and strategies adopted by the market in increasing their sales. This case will be helpful for marketing management course.

The case was written for use in marketing management classes at undergraduate and MBA levels. The focus of the case aligns well with discussions of sustainable marketing practices, societal marketing philosophy, building trust among consumers on your product, hard core loyalty nature of consumers and direct marketing. The case also has application in discussions regarding the implementation of sustainable marketing strategy. Instructors that choose to emphasize sustainable marketing strategy could assign this case to explore tradeoffs between

profitability, sustainability and consumer loyalty. Additionally, the case could also be used in food retail management courses.

\section{Learning Objectives}

By analyzing and discussing the case, reader should be able to:

1. Evaluate the contribution of sustainable production and marketing initiatives to a business's competitive advantage;

2. Analyze the tradeoffs between profitability, sustainability and consumer loyalty;

3. Develop an appropriate strategy for integrating farmers with urban consumers and developing a sustainable marketing model. 


\section{References}

1. Financial Express Newspaper. (2019). India wastes up to $16 \%$ of its agricultural produce; fruits, vegetables squandered the most. Available at https://www.financialexpress.com/economy/india-wastes-up-to-16-of-its-agriculturalproduce-fruits-vegetables-squandered-the-most/1661671/ Accessed on 1st April 2021. 